\title{
Tudományos munka a Partiumi Keresztény Egyetemen
}

\author{
BALOGH BRIGITTA
}

\section{Bevezetés}

$\mathbf{N}$ incs könnyú dolga annak a felsóoktatási intézménynek, amely az oka részben az, hogy - a romániai-erdélyi magyarság történetére általánosan jellemző módon - az államszocializmus évtizedei alatt a tudományos elit középgenerációjának jelentős része kivándorolt, így a kilencvenes évek elején éledezni kezdő intézményeknek nagy gondot okozott a fiatalokat kiképezni képes generációk visszavonzása. Ehhez járult még az a történeti adottság, hogy a (társadalom)földrajzi értelemben vett régió mentalitásában és hagyományos kulturális-gazdasági kapcsolataiban sok szemponból inkább kötődött Kelet-Magyarországhoz, mint Közép-Erdélyhez, ${ }^{1}$ így az akadémiai elitnek a régióba vonzásában is sajátos nehézségekkel kellett szembenéznie, nem beszélve az akadémiai infrastruktúra szinte teljes hiányáról. Ugyanakkor a feladat, hogy a Partium visszakerüljön a Kárpát-medencei magyar akadémiai szféra térképére, sürgető volt és ma is sürgető, tekintettel arra, hogy - mint másutt megfogalmaztam ${ }^{2}$ - a jó felsőoktatás egy közösség számára a hajszálnyi különbséget jelentheti az élet és a puszta

1 Lásd ehhez pl. Szilágyi Ferenc: A Partium közigazgatási földrajza. Debrecen, Debreceni Egyetem, 2009; Szilágyi Ferenc: Közigazgatás a Partiumban. Nagyvárad, Partium Kiadó, 2013; Szilágyi Ferenc - Zakota Zoltán (szerk.): Partium - társadalom-és térszerkezet. Nagyvárad, Dokumentum Kiadó, 2013. 2 Balogh Brigitta: Erdélyi magyar felsóoktatás-politika erdélyi szemmel. Századvég, új folyam, 77. sz. 2015/3. (Tudománypolitika), I2I-I42. 
vegetálás között. A nagyváradi Partiumi Keresztény Egyetem (PKE) ennek a feladatnak az ellátására vállalkozik.

\section{Intézményi keretek}

A PKE az 1990-ben elindított Sulyok István Református Főiskola jogutódja. A 200o-ben megalapított egyetem 2004-ben nyerte el a szakmai akkreditációt, ezt szentesítette négy év elteltével a I96/2008-IO-2I. törvény. A „keresztény” jelző az intézmény nevében nemcsak az egyházi háttérre utal (az alapító Pro Universitate Partium Alapítványt a történelmi magyar egyházak hozták létre, a jogelőd SIRF fenntartója pedig a Királyhágómelléki Református Egyházkerület volt), hanem arra az értékkészletre is, amelyet az egyetem képviselni óhajt: „Célunk olyan egyetemi közösség kialakítása, melyben a keresztényi szeretet, igazságosság, következetesség, szolidaritás, erkölcsös magatartás értékrendszere érvényesül és kisugárzik”. ${ }^{3}$

Az intézmény elsősorban regionális egyetemként definiálja magát, ami nemcsak arra a tényre vonatkozik, hogy a hallgatók nagy többsége a partiumi régióból kerül ki, hanem arra is, hogy az egyetem a régiót kiszolgáló tudásközponttá kíván válni, ami a tudományos kutatási portfólióban is tükröződik. A regionális elkötelezettséget sajátosan árnyalja a Partium határ mentisége, ami az intézményt különösen alkalmassá teszi mind a magyar-magyar, mind a magyar-román kapcsolatokat megkönnyítő hídszerepre.

A PKE jogilag magánegyetem, a magyar kormány által finanszírozott romániai magyar magánegyetemi hálózat része; azonban a hálózatnak szintén részét képező Sapientia Erdélyi Magyar Tudományegyetemmel együtt inkább a „közösségi egyetem” címke illene rá, tekintettel arra, hogy - egy jelentős nemzeti közösség felsőoktatási, kulturális és tudományos igényeit ellátva - mindkét intézmény közszolgálati feladatokat lát el. Ennek a közszolgálati jellegnek természetesen ára van, vagyis bármennyire is csábítóak az elsőrendúen gazdasági vagy népszerúségi szempontok, a képzési kínálat és a tudományos portfólió kialakításánál legalább annyira figyelembe kell venni a régió magyarságának fejlődését szolgáló kulturális reprodukciós ezáltal pedig nemzetstratégiai - feladatokat is. Ebből a szempontból stratégiai fontosságúak nemcsak a gazdasági, hanem a bölcsészettudományi és múvészeti képzések és kutatási irányok is, mindenekelőtt pedig a minőségi pedagógusképzés. Az egyetemet mindennek szellemében „történetének

3 A PKE küldetésnyilatkozata, http://www.partium.ro/hu/kuldetesnyilatkozat 
kezdetétől fogva az a felismerés vezérelt[e], hogy az erdélyi magyar kisebbség számára az anyanyelven szerveződő önálló egyetem ugyanolyan létkérdés, mint az anyanyelvú közoktatás teljes körú intézményrendszerének kialakítása. [...] Az értelmiségiek képzésével egyetemünk kultúrmissziós feladatokat is teljesít, biztosítva a szakember-utánpótlást az anyanyelvi kultúra átadására és továbbfejlesztésére". ${ }^{4}$

A PKE az oktatás és a kutatás egységének klasszikus akadémiai elvét vallja, ami egyrészt azt jelenti, hogy a kutatási területek és témák megállapításakor fontos szerepet játszanak az oktatási szükségletek, másrészt azt, hogy a kutatások eredményeit vissza kell forgatni az oktatásba, harmadrészt pedig azt, hogy a képzés egyben tudományos utánpótlás-nevelés is, aminek értelmében a hallgatókat igyekszünk bevonni a kutatói munkába is. Ez a törekvés természetesen csak a képzési szintek teljessé válásával (BA/BSc, $\mathrm{MA} / \mathrm{MSc}, \mathrm{PhD}$ ) tekinthető majd teljesnek, a doktori képzés beindításáig azonban a mesteri képzésre, valamint a képzéskiegészíto és tehetséggondozó intézményi formákra (szakkollégiumok, tudományos diákkörök) fókuszálva valósítható meg.

Az oktatás és a tudományos kutatás jelenleg háromkaros szervezeti keretben valósul meg. A Bölcsészettudományi Kar a nyelv- és irodalomtudományi, a társadalomtudományi, neveléstudományi, teológiai és filozófiai tanszékeket, illetve kutatóközpontokat, valamint a Tanárképző Intézetet foglalja magában. A Közgazdaságtudományi Kar a közgazdasági, gazdálkodási és pénzügyi oktatás és kutatás szervezeti hátterét nyújtja, míg a Múvészeti Kar a képzőmúvvészeti és zenei oktatásét, alkotásét és kutatásét. Az oktatást, illetve a kutatást az egyetemi könyvtár és az egyetemi kiadó, a Partium Kiadó szolgálja.

\section{A tudományos munka szervezeti keretei, fó megjelenési formái és a kutatástámogatás}

A PKE-n a tudományos munka elemi szervezeti kereteit a többnyire az egyes tanszékek köré szerveződő vagy kari kutatóközpontok, illetve kutatóintézetek adják, ezek jelen pillanatban a következők: Sulyok István Teológiai Kutatások Intézete, Partiumi Területi Kutatások Intézete, Filozófiai Kutatóintézet, Közgazdasági Kutatóintézet, Társadalomtudományi Kutatómúhely, Vizuális Alkotás és Nevelés Kutatómúhely (VAN), Zenei

4 Uo. 
Kutatómúhely, Germanisztikai Kutatómúhely, Anglisztikai Kutatómúhely, Modern Nyelvek Kutatómúhely. Ezeket a szervezeti kereteket egészítik ki a projektalapúan szerveződő kutatócsoportok. A múhelyekben megvalósuló munka rendszerességét, illetve hangsúlyait jól mutatják a köréjük szerveződo, illetve általuk szervezett tudományos rendezvények, különös tekintettel azokra a konferenciasorozatokra, amelyek rendszeres formában nyújtanak lehetőséget az adott szakterület tudományos eredményeinek közlésére, és amelyek szöveganyagai rendszeresen napvilágot látnak a Partium Kiadó gondozásában. Ilyenek például az idegen nyelvi tanszékek Internationale Germanistentagungen, illetve English Language \& Literatures in English konferenciasorozatai, a közgazdasági tanszékek International Conference on Emerging Economies sorozata vagy a Filozófia- és Kultúratudományi Tanszék Argumentor. International Conferences on Argumentation and Rhetoric sorozata.

I. TÁBLÁZAT: Tudományos rendezvények a PKE-n, 20IO-2015

\begin{tabular}{|c|c|c|c|}
\hline & Rendezvény & Szervezők & Időpont \\
\hline 1. & $\begin{array}{l}\text { ELLE (English Language and Literatures } \\
\text { in English) International Conference }\end{array}$ & $\begin{array}{l}\text { PKE, Károli } \\
\text { Gáspár Református } \\
\text { Egyetem }\end{array}$ & 2015 \\
\hline 2. & $\begin{array}{l}\text { Értelmiségi karrierek, irodalmi csoporto- } \\
\text { sulások, kapcsolathálók }\end{array}$ & PKE & 2015 \\
\hline 3. & $\begin{array}{l}\text { Trefort Ágoston Szakmai Tanárképzési } \\
\text { Konferencia }\end{array}$ & $\begin{array}{l}\text { Óbudai Egyetem, } \\
\text { PKE }\end{array}$ & 2015 \\
\hline 4. & A nyelv közösségi perspektívája & PKE & 2015 \\
\hline 5 . & $\begin{array}{l}\text { International Philip Roth: Across Cultu- } \\
\text { res, across Disciplines }\end{array}$ & $\begin{array}{l}\text { Philip Roth } \\
\text { Society, PKE }\end{array}$ & 2015 \\
\hline 6. & $\begin{array}{l}\text { Argumentor: Közbeszédaktusok. Ora- } \\
\text { dea, } 11 \text { septembrie } 2015 \text {. Organizatori: } \\
\text { Institutul de Cercetări Filosofice al Univ. } \\
\text { Creştine Partium; Departamentul de } \\
\text { Ştiințe Sociale al Univ. Sapientia; Depar- } \\
\text { tamentul de Filosofie al Univ. Debrecen }\end{array}$ & $\begin{array}{l}\text { PKE, } \\
\text { Sapientia EMTE, } \\
\text { Debreceni Egyetem }\end{array}$ & 2015 \\
\hline & Párbeszéd az idősgondozásról & PKE & 2015 \\
\hline 8. & Bartók Béla Kelet és Nyugat között & PKE & 2015 \\
\hline
\end{tabular}


9. ELLE (English Language \& Literatures in PKE, Károli Gás- 2014 English) International Conference pár Református

Egyetem

10. 3rd International ARGUMENTOR PKE, Sapientia 2014 Conference on Argumentation and EMTE, Debreceni Rhetoric (Ten Years of Facebook) Egyetem

11. Umwandlungen und Interferenzen. PKE 2014 6. Internationale Germanistentagung an der Christlichen Universität Partium

12. Ady Endre, Juhász Gyula és József Attila JAT - PKE 2014 A Holnap városában

13. Public Sociology and Social Intervention PKE, Magyar Szo- 2013 in the Carpathian Basin

ciológiai Társaság, Román Szociológiai

Társaság

14. ELLE (English Language \& Literatures PKE 2013 in English) 3rd International Conference

15. Human Capital Based Economics and PKE 2013 Human Scale Values. 3rd International Conference on Emerging Economies

16. Towards an Effective Regional Resource Allocation

PKE, Szegedi

2013 Tudományegyetem

17. Elastic Survey PKE, Szegedi 2013 Tudományegyetem

18. Értelmiségi karrierek, karrierminták, írói PKE 2013 csoportosulások. Társadalomtörténeti és irodalmi reprezentációk

19. Második ARGUMENTOR workshop PKE 2013

20. Együttmúködési és társulási formák a jövő gazdaságában PKE, Romániai 2013 Magyar Közgazdász

Társaság

$\begin{array}{lll}\text { 21. Időszerüség és tudományos rang } & \text { PKE } & 2013 \\ \text { 22. } \begin{array}{l}\text { Krisen als Wendepunkte in der Germa- } \\ \text { nistik. V. Internationale Germanisten- }\end{array} & \text { PKE } & 2012 \\ \text { tagung an der Christlichen Universität } & & \\ \text { Partium } & & \end{array}$


23. ELLE (English Language \& Literatures PKE

in English) 2nd International Conference

24. A Heidelbergi Káté tanításának létjogo- $\quad$ PKE 2012 sultsága a 21. században

25. Deutsche Sprache und Kultur im Banat PKE, 2012

Universität Wien

26. Argumentor. The Second Internatio- ${ }^{-}$PKE, 2012 nal Conference on Argumentation and Debreceni Egyetem Rhetoric

27. Kodály 130 . Kodály Zoltán

PKE

2012 Emlékkonferencia

28. European, National and PKE, Nagyváradi 2011 Regional Identity Egyetem, Debreceni Egyetem

29. ELLE (English Language \& Literatures in PKE 2011 English) 1st International Conference

30. Knowledge and Sustainable Economic PKE 2011 Development. 2nd International Conference on Emerging Economies

31. Birtalan József PKE 2011 Zenetudományi Konferencia

32. Liszt 200 Emlékkonferencia PKE 2011

33. „Ethnic Revival” workshopok (március: PKE, 2011 Nagyvárad, május: Hajdúböszörmény, Debreceni Egyetem június: Nagyvárad, július: Szatmárnémeti, október: Nagyvárad, Szatmárnémeti, november: Szatmárnémeti)

34. Első ARGUMENTOR workshop PKE 2011

35. Argumentor. The First International PKE 2010 Conference on Teaching Argumentation and Rhetoric

36. Interkulturelle Erkundungen. IV. InterPKE 2010 nationale Germanistentagung Partium

37. Az alkotás és múvészeti kutatás interPKE 2010 diszciplináris vonatkozásai 
A múhelyek keretében folyó, illetve az egyéni kutatási tevékenység eredményeit a PKE oktatói-kutatói a 2010 és 2015 közötti időszakban több mint Iooo tudományos publikáció, illetve konferencia-előadás formájában bocsátották a tudományos nyilvánosság rendelkezésére, ami átlagosan évi 2,5 publikációt és ugyanannyi tudományos előadást jelent egy főre.

A kutatásfinanszírozás - a belső finanszírozást és az egyéni kutatói ösztöndíjakat nem számítva - két fó forrásból valósul meg. Az első forrást a Sapientia Alapítvány kutatástámogatási intézetén, a Sapientia Kutatási Programok Intézetén (KPI) keresztül elnyerhető finanszírozás képezi. A KPI egyaránt finanszírozott rövidebb (I éves) és hosszabb (3 éves, az eredmények függvényében évente meghosszabbítható), egyéni avagy csoportos kutatásokat, az utóbbi években azonban a hangsúly az erdélyi magyar magánegyetemi hálózat szükségleteinek megfelelően a középtávú (I,5 év) csoportos kutatások támogatására került. Fontos eleme a KPI által alkalmazott rendszernek, hogy támogatja az egyetemi (jellemzően mesteri képzésben részt vevő) hallgatók bevonását a csoportos kutatásokba, ezzel is elősegitve a tudományos utánpótlás-nevelést. Ösztönző erejú továbbá a nemzetközi tudományos konferenciákon való részvétel finanszírozását célzó KPI-s pályázattípus is.

2. TÁBLÁZAT: A KPI által finanszírozott csoportos kutatások, 20IO-2OI5

Kutatás címe

Időtartam

1. Az interkulturális kommunikatív kompetencia fejleszté- 2015-2016 sének területei és módszerei a német szakos bölcsészképzésben (kutatásvezető: Bánffi-Benedek Andrea)

2. Hamis barátok a magyar és román nyelvben (kutatás$2015-2016$ vezető: Magyari Sára)

3. Xenológiai tanulmányok - a kelet-közép-európai irodal- 2015-2016 mak idegenképének kutatása (kutatásvezető: Varga Péter)

4. Egyenlóség vagy egyformaság? A társadalmi homo$2013-2014$ genitás mint a modern nyugati politikai kultúra hallgatólagos előfeltevése (kutatásvezető: Balogh Brigitta)

5. A beszédészlelés és a beszédmegértés jellemzői $2013-2014$ kisiskoláskorban (kutatásvezető: Bartha Krisztina)

6. Forrás és utóélet. Hálózatok, irodalmi $2013-2014$ csoportosulások A Holnap körül és árnyékában (kutatásvezető: Boka László) 
7. A székelyföldi amatőr és iskolai kórusmozgalom múltja 2013-2014 és jelene. Egy énekkari múhely perspektívái (kutatásvezető: Csákány Csilla)

8. Az anyanyelv képe (kutatásvezető: Magyari Sára) $2013-2014$

9. A magyar nemzeti hegemónia dilemmái a történelmi 2011-2014 Magyarország utolsó két évtizedében, különös tekintettel a Partiumra és a Bánságra (kutatásvezető: Molnár Gusztáv)

10. Topográfiai modellek a kelet-közép-európai mikrorégiók- 2013-2014 ban (kutatásvezető: Varga Péter)

11. A romániai magyar középfokú zenei szakoktatás múltja, 2012-2013 jelene és távlatai (kutatásvezetó: Fodor Attila)

12. A kis- és közepes vállalatok társadalmi felelósségvállalásá- 2011-2013 nak vizsgálata Erdélyben (kutatásvezető: Szász Erzsébet)

13. A határ menti együttmúködések alakulása a román- 2011-2012 magyar államhatár északi szakaszán (kutatásvezetó: Szilágyi Ferenc)

14. Nemzedéki múvészeti nyelvezetek (kutatásvezető: Antik 2011-2012 Sándor)

15. Az irónia mint filozófiai attitüd és esztétikai értékkategó- $2009-2011$ ria (kutatásvezető: Horváth Gizella)

16. Birtalan József élete és zeneszerzői munkássága (kutatás- 2009-2011 vezető: Boros-Konrád Erzsébet)

A második típusú finanszírozási forrást a jellemzően nemzetközi, más intézményekkel együttmúködésben megpályázható európai uniós programok képezik, amelyek közül a PKE-nek főként a Regionális Fejlesztési Alap által koordinált határ menti együttmúködési programok keretében folytak nagyobb lélegzetû́ kutatásai. 
3. тÁвLÁZAT: Az EU Regionális Fejlesztési Alapja által társfinanszírozott nemzetközi kutatások, illetve kutatási komponenst is tartalmazó nemzetközi projektek, 2009-2013

\begin{tabular}{|c|c|c|c|}
\hline & Kutatás, ill. projekt címe & Keretprogram & Időszak \\
\hline & $\begin{array}{l}\text { HURO/1001/268/2.3.1: } \\
\text { SOCIALPROF } \\
\text { - Deepening of cross-border cooperation } \\
\text { in the field of training and labour market } \\
\text { orientation of social professionals }\end{array}$ & HURO/1001 & $2012-2013$ \\
\hline 2. & $\begin{array}{l}\text { HURO/1001/320/2.2.3: FICON - The } \\
\text { research of the financial contagion phe- } \\
\text { nomenon, in terms of risk and stochasti- } \\
\text { city for a healthy regional economy }\end{array}$ & HURO/1001 & $2012-2013$ \\
\hline 3. & $\begin{array}{l}\text { HURO/1001/293/2.2.3: LEDIRE } \\
\text { - Levy distribution for the study of } \\
\text { predictability indicators, with impact } \\
\text { on regional development }\end{array}$ & HURO/1001 & $2012-2013$ \\
\hline 4. & $\begin{array}{l}\text { HURO/1001/209/2.3.4: TERRA - } \\
\text { Towards Effective Regional Resource } \\
\text { Allocation }\end{array}$ & HURO/1001 & $2012-2013$ \\
\hline 5. & $\begin{array}{l}\text { HURO/0901/077/1.2.2: BORDER- } \\
\text { LAND - Community Learning Ressour- } \\
\text { ce Center }\end{array}$ & HURO/0901 & $2012-2013$ \\
\hline 6. & $\begin{array}{l}\text { HURO/0901/203/2.3.1: „Adult } \\
\text { Learning” - Promoting the integration } \\
\text { of disadvantaged groups through coope- } \\
\text { ration in the field of adult learning and } \\
\text { professional training in the Bihor-Hajdu- } \\
\text { Bihar Euro-region }\end{array}$ & HURO/0901 & 2011-2012 \\
\hline 7. & $\begin{array}{l}\text { HURO/0901/042/2.3.1: „Ethnic Revi- } \\
\text { val” - Equality of chances in keeping } \\
\text { the local identity and reorganizing the } \\
\text { education and professional training }\end{array}$ & HURO/0901 & $2011-2012$ \\
\hline 8. & $\begin{array}{l}\text { HURO/0901/253/2.2.2: HERD - } \\
\text { Higher Education for social cohesion - } \\
\text { cooperative Research and Development } \\
\text { in a cross-border area }\end{array}$ & HURO/0901 & $2011-2012$ \\
\hline
\end{tabular}


9. HURO/0901/255: CaDS-SMsE -

HURO/0901 2011-2012

Computational support for the decision

making of the cross-border SMEs

10. HURO/0801/054: CEPEVIT -

HURO/0801 2010-2011

Cross-border perspectives of the con-

versions in the relation of the centre and

the periphery in the context of cultural

regionalism and contemporary visual

culture

11. HURO/0801/180: ENRI

HURO 0801 2009-2011

- European, National and Regional

Identity - Theory and Practice

12. HURO/0801/108: „Roma Employment” HURO/0801 2009-2010

- Facilitating the Employment of Roma in the Bihor - Hajdú-Bihar Euro-region

13. HURO/0801/020: COMPETENTLY HURO/0801 2009-2010 - Enhancement of the intercultural competences of the pedagogue-communities in the Hungarian-Romanian border regions

14. HURO/0801/178 (2009-2010): HURO/0801 2009-2010 BEST PRACTICE - Best practice based rural tourism host and courier training for tourism development of the border regions

15. HURO/0801/027: Woman and Nature HURO/ 2008-2009

- Women and Nature - Program Series on Enhancing Feminine Identity

\section{Kutatási stratégia}

Az egyetem 20I3-ban elfogadott középtávú, 20I8-ig szóló kutatási stratégiája az aktuális helyzet elemzéséból kiindulva határozza meg a legfontosabb kutatásszervezési célkitúzéseket, valamint az egyetem sajátosságai és az oktatók-kutatók kutatási háttere alapján meghatároz néhány olyan 
tematikus kutatási területet, amelyekre koncentrálva érdemes fejleszteni az egyetem tudományos arculatát.

A stratégia súlypontjainak hátterét árnyalja a romániai oktatási (akkor oktatási, kutatási és iffúságügyi) minisztérium 20II-ben elvégzett felmérése. A felmérés a romániai felsőoktatási intézmények úgynevezett „osztályozását" lett volna hivatott elvégezni, amellyel kapcsolatban következetesen hangsúlyozták, hogy nem minőségi besorolás kíván lenni, hanem az egyes intézmények profilját hivatott pontosítani, és ez utóbbi cél érdekében sorolják be az egyetemeket az oktató, oktató-kutató és elsődlegesen kutató egyetemi kategóriákba. Az értékelés elsődleges szépséghibáját az jelentette, hogy a besorolás kritériumait soha nem hozták nyilvánosságra, s így azt sem tudjuk, az értékelésnél használt mutatókat egyáltalán differenciálták-e a rangsorolásban részt vevő intézmények méretéhez arányosítva. A PKE mindenesetre - hasonlóan a romániai magánegyetemek többségéhez, amelyek közül egy intézmény sem kapott kutatóegyetemi besorolást - az „oktatóegyetem” kategóriába került, ami értelemszerúen kirajzolta az elsődleges stratégiai célt, nevezetesen az intézményben folyó tudományos munka nemzetközi láthatóságának javítását. Természetesen úgy, hogy ez ne menjen az egyetem közösségi és regionális küldetésének rovására. Emellett két további stratégiai cél került megfogalmazásra. Az egyik egy olyan jellegzetes kutatási portfólió kialakítása, amely egyértelmúen beazonosíthatóvá teszi az egyetemet a térség tudományos palettáján, a másik pedig az örök érvényú technikai cél, a kutatás infrastrukturális körülményeinek javítása.

A nemzetközi láthatóság javításának leofőbb eszköze a PKE minőségbiztosítási rendszerének részét képező, az oktatók/kutatók éves tudományos teljesítményéről számot adó önértékelési úrlap módosítása oly módon, hogy az egyes teljesítménytípusokkal szerezhető pontszámok tekintetében leginkább a nemzetközi publikációkat díjazza, illetve instrumentális értéküket elismerve relatíve magas pontszámokkal értékeli a nemzetközi rangú tudományos konferenciákon való részvételt is.

Az egyetemspecifikus kutatási portfólió kialakítása, illetve fejlesztése érdekében az intézmény megpróbálta összhangba hozni egymással az oktatók-kutatók már meglévő kutatási hátterét és a PKE regionális státusából adódó kutatási szükségleteket. Ennek nyomán hét olyan tematikus kutatási terület került azonosításra, amelyek az említett portfólió gerincét képezhetik: I) nyelv, kultúra, identitás; 2) régiófejlesztés és regionális kutatások; 3) romániai magyarság, illetve egymás mellett élő erdélyi kultúrák; 4) a társadalmi igazságosság elméletei és gyakorlatai; 5) gazdasági, társa- 
dalmi és ökológiai fenntarthatóság; 6) felsőoktatás és oktatási környezet; 7) múvészet és kommunikációs médiumok.

Többek között a kutatási stratégia tekintetében is sajátos visszacsatolási lehetőséget jelentett az az intézményi értékelési eljárás, amelyet egy kormányprojektnek köszönhetóen EU-s finanszírozásból az Európai Egyetemek Szövetségének (EUA) minőségbiztosítási szakértői végeztek a PKE-n 2013-20I4-ben. A két helyszíni látogatást is magában foglaló felmérés nyomán keletkezett zárójelentés kiemeli a kutatási stratégia célszerú voltát, illetve azzal összhangban hangsúlyozza a multidiszciplináris regionális kutatások jelentőségét a PKE tudományos jövője szempontjából. ${ }^{5}$

\section{Tematikus súlypontok}

A következőkben röviden áttekintjük a PKE kutatási stratégiája által meghatározott hét fó tematikus kutatási területet, a teljesség igénye nélkül hozzájuk rendelve néhány, az adott területen folyó kutatást.

A „nyelv, kultúra, identitás” kutatási területen belül a stratégia a következő vonatkozásokat hangsúlyozza: nemzeti identitás és kulturális emlékezet; nyelvi kompetenciák; interkulturalitás, transzkulturalitás, interkulturális kompetenciák; többes identitás és multikulturális hovatartozás; a személyes, kulturális és nemzeti identitás narratív képződése; többnyelvúség; kulturális alkotások befogadásának és értelmezésének modern módszerei; kulturális attitúdök, múvészettel kapcsolatos attitúdök. A „romániai magyarság, erdélyi kultúrák" kutatási terület a következő fó vonatkozásokat foglalja magában: az erdélyi magyar kultúra, illetve az erdélyi kultúrák nemzetközi recepciója; román-magyar kulturális transzfer, román-magyar interetnikus viszonyok; a kortárs magyar, illetve román irodalom nemzetközi recepciója; erdélyi közösségek és kultúrájuk; erdélyi zenei élet, erdélyi képzőmúvészet.

A terület gazdagsága a vonatkozó kutatásokban részt vevő tudományágak sokféleségében is megmutatkozik, hiszen ezek azok a témák, amelyek vizsgálatakor jellegzetesen találkoznak a társadalomtudományi, kultúratudományi, nyelvtudományi és történeti szempontok. Nyelvészeti téren

5 „The university has an excellent research strategy, with clear priorities and milestones and the intention of developing multidisciplinarity in this area. [...] because this border region has been at the centre of European history, a regional research of high quality would have international appeal." Carles Solà - Krista Varantola - Jacob Müller - Andrée Sursock: Partium Christian University. Evaluation Report. European University Association, Institutional Evaluation Programme, 20I4. 22-23. http://www.eua.be/Libraries/iep/IEP_RO_Final_Report_PCU.pdf?sfvrsn=O 
említést érdemelnek például a frazeologizmuskutatások és a kontrasztív grammatikai kutatások, valamint a kétnyelvúséggel kapcsolatos kutatások, a beszédfeldolgozás sajátosságainak vizsgálatától a nyelvek idiomatikus kifejezéseinek vagy a különböző médiumokban használatos fordítási technikáknak az összehasonlításáig. Különösen jelentősek a magyar mint idegen nyelv oktatására vonatkozó kutatások, illetve az antropológiai nyelvészeti, szemiotikai vonatkozások is. Az irodalmi kutatások terén jelentős területeket képeznek a nyelvváltással, illetve a nyelvek összefonódásával, valamint a következő további témákkal kapcsolatos vizsgálódások: identitásképződés különböző korokból származó, különböző nyelveken született autobiográfiák tükrében; térábrázolás és emlékezetkultúra kapcsolata, topográfiai modellek a kelet-közép-európai irodalmakban; intermedialitás és narratív identitás; identitásképzés posztkoloniális irodalmi szövegekben; identitásreprezentációk a magyar, a román, a német és az angol nyelvú irodalmakban; erdélyi német kultúra és sajtótörténet.

A nyelvi, narratív, kulturális, illetve nemzeti identitás problémái köré szerveződnek továbbá a különféle identitásreprezentációkat vizsgáló kutatások, amelyek a kulturális reprezentációknak és a (nemzeti) identitásnak az irodalomban való megjelenésétől a kánonkutatásig, az időfogalmak, időreprezentációk vizsgálatától az európai és lokális identitás élettörténetekben való megnyilvnulásáig terjednek. Mind a nyelvi-nyelvészeti, kultúratudományi, mind a társadalomtudományi megközelítés számára különösen izgalmas a kisebbségi identitás problémája, különös tekintettel a többszörös kisebbségi helyzet identitásban való tükröződésére. Ehhez a témakörhöz tartoznak többek között a kettős kisebbségi létben élő roma fiatalok érvényesülési esélyeit, a kettős siket-magyar identitást, illetve a különböző kultúrák kontextusában értelmezésre kerülő zsidó identitást vizsgáló kutatások. Hasonlóan izgalmas és sokrétú kérdésfeltevést biztosító kutatások azok, amelyek a magyar-román kulturális transzfer jelenségeit, illetve a többszörös (pl. román-német-zsidó) kulturális transzfer egyes jelenségeit vizsgálják. A nyelvészeti kutatások érintett ágát képezi az antropológiai nyelvészet, illetve a kulturális nyelvészet, ezenbelül pedig a nyelvi világképkutatás, illetve a kulturális különbségek diagnosztizálása a nyelvhasználatban; a társadalomtudományi tanszéknek pedig az egyik klasszikusnak mondható kutatási területe a vallási és nemzeti identitás, gyakran ifjúságszociológiai szempontokkal kombinálva.

A PKE-n folyó történeti jellegú kutatások is ezt a kutatási irányt erősítik. Ezek tárgyai többek között az erdélyi magyar zenekultúra, a romániai magyar társadalomtudomány-történet, a kortárs magyar irodalom- és társa- 
dalomtörténet, valamint a kulturális intézmények története, különös tekintettel a színház-, illetve iskolatörténetre.

„Regionális fejlesztés” címszó alatt a PKE kutatási stratégiája a következő kutatási irányokat hangsúlyozza: a regionális fejlődés és fejlesztés kulturális, társadalmi és gazdasági vetületei; gazdasági folyamatok Erdélyben, határ menti együttmúködések; a romániai magyarság gazdasági tevékenysége; falusi turizmus; kulturális turizmus. Ide sorolhatók mindenekelőtt a közgazdasági, illetve a társadalomtudományi tanszékek vonzáskörzetében folyó kutatások, melyek jellegzetes ágát képezi a társadalom- és közigazgatási földrajz, valamint a partiumi régiót meghatározó gazdasági, társadalmi és kulturális kapcsolathálóra vonatkozó kutatások. Hasonlóképpen fontos regionális implikációkkal bírnak az agrár-közgazdaságtani kutatások is, valamint a határ menti régiók dinamikájára vonatkozó kutatások.

„A társadalmi igazságosság elmélete és gyakorlata”, valamint a „gazdasági, társadalmi és ökológiai fenntarthatóság” kategóriákba olyan témák tartoznak, mint: társadalmi inklúzió, szolidaritás; esélyegyenlőség; igazságosságkoncepciók multietnikus/multikulturális társadalmakban; társadalmi felelősségvállalás; gazdasági és társadalmi fenntarthatóság a globalizáció kontextusában. A téma jellegzetessége, hogy mind elvi, mind gyakorlati szinten igen széles skálán vizsgálható, s ez a PKE portfóliójában is megmutatkozik: a vonatkozó kutatások között éppúgy találhatunk elméleti jellegú alapkutatásokat, mint egy-egy nagyon konkrét problémahalmazt vizsgáló empirikus kutatásokat. Néhány téma ezek közül: a régió szociális és gyermekvédelmi intézményrendszerének hatékonysága; az erdélyi kis- és középvállalkozások társadalmi felelősségvállalása; a bizalom közgazdaságtanilag értelmezhető fogalma és az ezzel kapcsolatos gazdaságetikai kérdések; pénzügyi válságok mélyebb gyökerei; hátrányos helyzetú csoportok szociális exklúziója/inklúziója.

A „felsőoktatás és oktatási környezet” tematika a következő fő kutatási irányokat tartalmazza: oktatási elvek és oktatáspolitika; pedagógiai módszertan és szakmódszertanok; felsőoktatás a társadalmi folyamatok és az oktatási rendszer kontextusában; interkulturális nevelés; romániai magyar nyelvú oktatás; zenei, vizuális, múvészeti nevelés. A kutatási terület természetes módon átfedésben van más kutatási területekkel, fóként azokkal, amelyek az oktatás szociokulturális környezetét és intézményi hátterét vizsgálják. Közelebbről idetartoznak a következő konkrét kutatások: a magyar mint idegen nyelv oktatása szórványközösségekben; az idegennyelv-oktatás módszertani kérdései; matematikai didaktika; szövegértés-fejlesztés; a problémamegoldó készség fejlesztése, térbeli reprezentációk szerepe a 
problémamegoldásban; pedagógusok tanuló szakmai közösségei; hátrányos helyzetú fiatalok érvényesülési esélyei stb.

Végül a „múvvészet és kommunikációs médiumok” terület tartalmazza az intermedialitásra, az online kommunikációra/kultúrára/gazdaságra, valamint a vizuális kommunikációra vonatkozó kutatásokat. Idesorolhatók a nyelvi tanszékeken folyó következő kutatások: zene és líra, illetve film és irodalmi mú intermedialitása, filmszemiotikai megközelítések, filmadaptációk; intermedialitás és narratív identitás. Főként a nyelvi tanszékek keretében folynak speciális nyelvhasználati területekre vonatkozó kutatások (pl. sajtónyelv, online nyelvhasználat), a közgazdasági tanszékeken többen foglalkoznak online marketinggel, a múvvészeti tanszékeken pedig - természetesen a szúkebb értelemben vett múvészi munka mellett - az intermédia-kutatások, illetve a kortárs esztétika, stilisztika és múvészetelmélet területén végzett vizsgálódások jellemzőek.

\section{Távlati célok}

Ami az intézmény tudományos jövőjét illeti, a legfontosabb célok egyértelmúnek látszanak. A sajátos kutatási portfólió kialakítása az adatok szerint folyamatban van, az viszont, hogy a nemzetközi láthatóság növelése mennyiben emelte reálisan az intézmény tudományos presztízsét, további vizsgálatot és értékelést kíván. Az intézmény mindenesetre csak akkor fog eljutni a tudományos nagykorúság állapotába, ha az egyetemi oktatás harmadik szintjét, a doktori képzést is sikerül elindítania. Az ebben az irányban tett legfontosabb lépés az Eötvös Loránd Tudományegyetemmel létrejött megállapodás a doktori képzés távlati beindításához szükséges humánerőforrás-fejlesztés terén történő együttmúködésről, de a régió többi felsőoktatási intézményével, mindenekelőtt a Debreceni Egyetemmel fenntartott szoros szakmai együttmúködés is ebbe az irányba mutat. A doktori képzés előkészítésének során emellett egyre nagyobb súlyt kell kapnia a tudományos utánpótlás-nevelésnek, vagyis a mesterképzés keretében folyó hallgatói kutatómunka továbbfejlesztésének és a tudományos diákkörök megerősítésének. 